a common role in a process whose only feature may be an axial arrangement of tissues. It would thus also be premature to surmise that, if such homoeobox sequences are truly ancestral, the conservation of such a sequence reflects a common ancestral lineage for invertebrates and vertebrates in the development of segmentation controlled by a common, homologous DNA sequence.

However, alternative possibilities exist. Leaving aside convergent evolution, an ancestral homoeobox sequence may have been usurped or recruited for different functions in different morphogenetic processes in separate evolutionary lineages, and although invertebrates and vertebrates possess a common homoeodomain, it may possibly be involved with quite different aspects of development. Given a possible DNA-binding role for the homoeobox sequence $^{12}$ the homoeo-product may have a common function within different morphogenetic processes in separate evolutionary lineages, thus explaining its continued conservation.

Therefore, it seems to us somewhat premature to associate homoeobox sequences wholeheartedly with vertebrate segmentation and the control thereof. There is clearly an inherent danger in establishing such a model. It is too soon to rule out the role of homoeoboxes in morphogenetic processes other than segmentation.

S.D.M. BROWN

A.J. GREENFIELD

Biochemistry Department,

St Mary's Hospital Medical School,

London W2 IPG, UK

1. Lewis, E.B. Nature 276, 565-570 (1978).

2. Bender, W. et al. Science 221, 23.29 (1983).

3.-Struhl, G. Nature 308. 454-457 (1984).

4. Struhl, G. Proc, nain. Acad. Sci. U.S.A. 79, 7380-7384 (1982)

5. McGinnis, W. et al. Cell 37, 403-408.

6. McGinnis W. et al. Nature 308, 428-433 (1984)

7. Levine, M. el al. Cell 38,667.673 (1984).

8. Akam, M. Nature 308, 402-403 (1984).

8. Akam, M. Nature $308,402-403$ (1984).
9. Romer, A.S. The Vertebrate Body 4 th edn (Saunders,

Romer, A.S. The

Baltimore, 1970).
0. Hyman, L.H. (omparative Vertebrate Anatomy

(University of Chicago Press, 1943)

11. McGinnis, W. el al. Cell 38, $675-680$ (1984).

12. Shepherd, J.C.W. et al. Nature 310, $70-7 !$ (1984).

13. Mueller, M. el al. Cell 39, 157-162 (1984).

\section{T-cell receptor genes and ataxia telangiectasia}

SIR - The nature of the T-cell antigen receptor has been recently discussed in News and Views ${ }^{1}$. The genes for the $\beta$ chain of the $T$-cell receptor have been cloned and mapped and human chromosome 7 , bands $7 \mathrm{p} 13-21^{2}$, while the $\alpha$-chain genes still await chromosomal assignment. We wish to draw attention to some observations which might indirectly bear on the latter issue as well as on the pathogenesis of immunodeficiency in human disease.

It is known that in lymphocytes from individuals with the chromosomal instability syndrome ataxia telangiectasia (AT), 7-14 translocations appear to be a nonrandom event (their frequency is more than 40 times higher than expected $)^{3+6}$. Break- points on these chromosomes are also highly nonrandom, involving bands $7 \mathrm{p} 14$ (consistently with the position of the $\mathrm{T}$-cell receptor $\beta$-chain genes), $7 q 35,14 q 12$ and $14 \mathrm{q} 32$ (consistently with the known position of the immunoglobulin heavychain genes). The relative frequencies of breaks at $7 \mathrm{p} 14$ versus $7 \mathrm{q} 35$, and at $14 \mathrm{q} 12$ versus $14 q 32$ are $1: 1$ and $3: 1$, respectively ${ }^{3-6}$. It is reasonable to speculate that the spontaneous breakages at bands 7 p14 and $14 \mathrm{q} 32$ in AT lymphocytes originate from faulty rearrangements of the T- and B-cell receptor genes which map there. This also suggests that these genes are normally rejoined, during rearrangement, by the same repair mechanism which is defective in $\mathrm{AT}$, thus providing a basis for the $\mathrm{T}$-and $B$-cell immunodeficiency characteristic of this syndrome ${ }^{7}$. The fact that 7-14 translocations are found in $\mathrm{T}$-lymphocytes might indicate that both chromosomes contain genes which rearrange in these cells. The nonrandom breakpoints at bands $7 q 35$ and $14 q 12$ may reflect the positions of two different sets of rearranging $\mathrm{T}$-cell receptor genes, for example the $\alpha$-chain and the so-called non- $\alpha$ genes' ${ }^{1}$.

M. FIORILLI

M. CARBonarI

M. CRESCENZI

G. RUSSO

F. AIUTI

Department of Clinical Immunology,

University of Rome,

Rome 00186, Italy

1. Robertson, M. Nature 312, 16-17 (1984).

. Caccia, N. et al. Cell 37, 1091-1099(1984)

Hecht, F. et al. Nature 255, 243-244 (1975)

4. Hecht, F. \& Kaiser-McCaw, B. in Ataxia-Telangiectasia: a Cellular and Molecular Link Between Cancer. Neuropath ology and Immune Deficiency (eds Bridges, B.A. \& Harnden, D.G.) 235-241 (Wiley, New York, 1982).

O'Connor, R.D. et al. ibid. 259-270.

Taylor, A.M.R. ibid. 53-81.

Fiorilli M. el al. J. clin. Immun. 3, 135-141 (1983).

\section{Medical versus animal} antibiotics in resistance

SIR - In his letter on "animal antibiotics", A. H. Linton' says that "the present debate [on resistance] ... hinges on whether or not subinhibitory, rather than prophylactic or therapeutic levels of antibiotics play the major role". I believe that subtherapeutic, rather than subinhibitory, levels fed to animals are central to the present debate. Even though there is laboratory work on subinhibitory levels, these low levels are not added to animal feeds.

As cited by Linton', there is a large reservoir of $\mathbf{R}$ plasmid-carrying indigenous flora in the intestines of animals ${ }^{2}$, but these flora are not necessarily a significant source of resistance for human pathogens. For example, ampicillin-resistant Neisseria gonorrhoeae probably derives its resistance from human origins ${ }^{3}$.

The suggestion that the energy cost to bacteria of carrying $\mathrm{R}$ plasmids places them at a disadvantage has been negated in some studies, but has found support in others, as discussed by Timoney and Linton ${ }^{4}$. Rough cultures of Salmonella choleraesuis var. kunzedorf, with associated reduced virulence, were found to be better recipients of $\mathbf{R}$ factors than were their smooth virulent parental counterparts. 5 .

Richmond and (K.B.) Linton ${ }^{6}$ found that sewage from hospitals contained more resistant organisms than did domestic sewage. They concluded that the main selective pressure for tetracycline-resistant organisms was from medical rather than veterinary use of antibiotics.

THOMAS H. JUKES

Department of Biophysics and Medical

Physics, University of California,

Berkeley, Oakland, California 94608 ,

USA

1. Linton, A.H. Nature 312, 96 (1984)

2. Linton, A.H. \& Hinton, M.H. in Antimicrobials and Agriculture (ed. Woodbine, M.) 533-549 (Butterworth, London, 1984).

. Wescoe, W.C. in FDA National Advisory Food and Drug Committee Report, p.27 (24 January 1977).

4. Timoney, J.F. \& Linton, A.H. J. appl. Bact. 52, $417-424$ (1982).

Jarolmen, H. \& Kemp, G. J. Bact. $97,962.963$ (1969).

6. Richmond, M.H.\& Linton, K.B. J. antimicrob. Chemother. 6, 33-44 (1980).

\section{Globulin flexibility} worked out by hand

SIR - Pirie's recent note' , about the flexibility of globulin molecules and the comfort of transposing left and right shoes, misses the main point of the the original model $^{2}$. It proposes that (-)abscisic acid can fit into the normal active site of a receptor (affecting growth inhibition) which is normally filled by natural $(+) \mathrm{ABA}$, provided that the $2^{\prime}$-methyl of the $(-)$ can occupy the site of a $6^{\prime}$-methyl group of the $(+)$, and a $6^{\prime}$-methyl of the (-) fits into the place which is occupied by the $2^{\prime}$-methyl of the $(+)$. This transposition could occur without distortion.

It is analogous to putting the little finger of a left hand into the thumb of a right glove and one's thumb into the little finger's position. The procedure can be carried out without discomfort and provides an appropriate mode for the similar action of the two enantiomers of ABA.

Pirie puts his foot in; a more evenhanded approach is suggested:

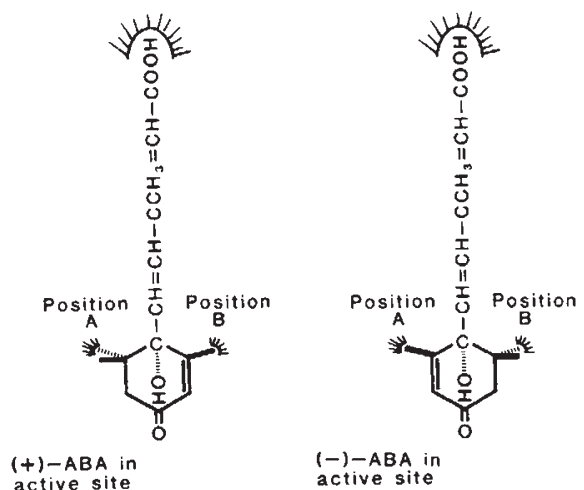

B.V. MILBORROW

School of Biochemistry,

The University of New South Wales, PO Box 1, Kensington,

New South Wales, Australia 2033

1. Pirie N.W. Nature 311, 18 (1984).

2. Milborrow, B.V. Rec. Adv. Phytochem 7, 67 (1974) 